\title{
Maize topcrosses for yield performance by additive main effects and multiplicative interaction analysis
}

\author{
Jocimar Costa Rosa ${ }^{1 *}$ Carlos Alberto Scapim ${ }^{1} @$ Marcos Ventura Faria ${ }^{2} @$ \\ Renan Santos Uhdre ${ }^{1}$ Welton Luiz Zaluski ${ }^{2}$ Vitor Seiti Sagae ${ }^{2}(\mathbb{B})$
}

${ }^{1}$ Departamento de Genética e Melhoramento, Universidade Estadual de Maringá (UEM), 5790, Maringá, PR, Brasil. E-mail: joce_jcosta@hotmail.com. ${ }^{*}$ Corresponding author.

${ }^{2}$ Departamento de Agronomia, Universidade Estadual do Centro-Oeste (UNICENTRO), Guarapuava, PR, Brasil.

ABSTRACT: The analysis of main additive effects and multiplicative interaction is commonly used in the evaluation of the genotype $x$ environment interaction, however, its application can be used for other purposes, as it is performed in the presentresearch, which uses this technique in the selection of inbred lines, testers and hybrids in maize topcrosses. Thisresearch determined the effect of the inbred lines $x$ testers interaction through the analysis of main additive effects and multiplicative interaction, verifying their efficiency in the selection of inbred lines, testers and hybrid combinations in topcrosses. The trials were carried out in the 2015/16 and 2016/17 crop seasons, with a complete block design, with three replications. Thirty $S_{3}$ maize inbred lines were evaluated in crosses with the AG8025, P30B39, MLP102, 60.H23.1 and 70.H26.1 testers forming 150 hybrids topcrosses. The trait evaluated was grain yield. The adaptability and stability of testers and inbred lines were evaluated by the methodology of analysis of main additive effects and multiplicative interaction directed to the interaction of testers $x$ inbred lines. The 96.3 inbred line has the most homogeneous performance and the highest grain yield, considering the crossing with all testers in both environments. The 70.H26.1 tester is considered the most stable and the most recommended for topcrosses. The best specific combinations were $96.3 \times 70$. H26.1 and $96.3 \times 60 . H 23.1$.

Key words: AMMI, inbred lines x testers interaction, partial diallel, Zea mays $L$.

Seleção de topcrosses de milho para rendimento de grãos por meio da análise de efeitos principais aditivos e interação multiplicativa

RESUMO: A análise dos principais efeitos aditivos e interação multiplicativa é comumente utilizada na avaliação da interação genótipo $x$ ambiente, porém, sua aplicação pode ser estendida para outros propósitos assim como realizado no presente trabalho em que utiliza esta técnica na seleção de linhagens, testadores e híbridos em topcrosses de milho. O objetivo deste trabalho foi determinar o efeito da interação linhagens $x$ testadores por meio da análise dos principais efeitos aditivos e da interação multiplicativa, verificando sua eficiência na seleção de linhagens, testadoras e combinações híbridas em topcrosses. Os ensaios foram realizados nas safras 2015/16 e 2016/17, com delineamento em blocos completos, com três repetições. Trinta linhagens de milho S3 foram avaliadas em cruzamentos com os testadores AG8025, P30B39, MLP102, 60.H23.1 e 70.H26.1 formando 150 topcrosses hibridos. A característica avaliada foi a produtividade de grãos. A adaptabilidade e estabilidade de testadores e linhagens foram avaliadas pela metodologia de análise de efeitos aditivos principais e interação multiplicativa direcionada à interação testadores x linhagens. A linhagem 96.3 apresentou o desempenho mais homogêneo e o maior rendimento de grãos, considerando o cruzamento com todos os testadores em ambos os ambientes. O testador 70.H26.1 é considerado o mais estável e o mais recomendado para topcrosses. As melhores combinações especificas foram $96.3 \times 70 . H 26.1$ e 96.3 $x$ 60.H23.1.

Palavras-chave: AMMI, interação linhagens $x$ testadores, dialelo parcial, Zea mays $L$.

\section{INTRODUCTION}

The analysis of main additive effects and multiplicative interaction (AMMI) stands out for allowing a more detailed assessment of the interaction between genotypes $\mathrm{x}$ environments $(\mathrm{GxE})$, providing more accurate estimates of genotypic responses, allowing an easy graphical interpretation of results, in addition to generating conclusions about stability, genetic divergence between genotypes and identifying the environments that optimized the performance of the evaluated genotypes. This analysis combines, in a single model, the analysis of variance performed through additive effects of genotypes and environments and the analysis of principal components that is based on the multiplicative effects of the GxE interaction (GAUCH \& ZOBEL, 1988; ZOBEL et al., 1988), allowing greater detail of the partition of sum of squares and interpretation of components that act in the interaction.

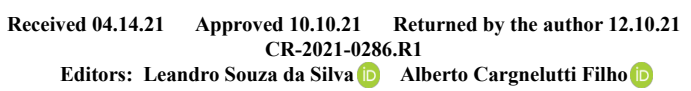


The AMMI analysis is commonly used to evaluate the GxE interaction (BOŢOVIĆ et al., 2018; GAUCH \& ZOBEL, 1988; HONGYU et al., 2015; ZOBEL et al., 1988); however, its applicability can be extended to other purposes, as it is performed in the present research, where this methodology is used for the selection of inbred lines and testers in topcrosses, as well as for the study and partition of additive and multiplicative effects of the inbred lines $\mathrm{x}$ testers interaction (ILXT) (CHARCOSSET et al., 1993).

CHARCOSSET et al. (1993) initiated studies related to the interaction between inbred lines and testers; however, further studies are needed to validate the action of the additive and multiplicative effects of the interaction (ILxT). Thus, the use of the AMMI model can become an efficient method in the selection of inbred lines, testers and study of the interaction like performed for KUMAR et al. (2020) and RUSWANDI et al. (2020).

The topcross method is widely used in plant breeding, but even though treated as efficient, it still presents, in its methodology, aspects that cause divergences between researchers, mainly in relation to the choice of the tester (DAVIS, 1927). It is not possible to determine a suitable tester for all crosses when there is a large number of inbred lines, mainly due to the fact that some inbred lines are eliminated because the tester used has low combining ability, influences heterogeneously with dominant or epistatic alleles (VENCOVSKY \& BARRIGA, 1992). Another aggravating factor is that when the ILxT interaction is verified in topcross evaluations, in most cases through the analysis of variance and the use of the additive model, this one is only mentioned without considering the partition, multiplicative effects or the respective contribution of each parent to a significant effect of the interaction (CANDIDO et al., 2020; HEINZ et al., 2019).

This study determined the interaction effect of inbred lines $x$ testers through the analysis of main additive effects and multiplicative interaction, verifying their efficiency in the selection of inbred lines, testers and hybrid combinations in maize topcrosses.

\section{MATERIALS AND METHODS}

Thirty $\mathrm{S}_{3}$ maize inbred lines from the simple hybrid SG6015 were crossed with five testers in topcrosses (the single hybrids AG8025 and P30B39), the mixture of lines MLP102 (from hybrids P30F53 and AG8080) and the elite lines 60.H23. 1 (from hybrid A2560) and 70.H26.1 (from hybrid
P30F33). The mixture of inbred lines is characterized by a broad genetic base, while the other testers have a narrow genetic base.

The trials were conducted in two consecutive years, in the $2015 / 16$ (ENV 1) and 2016/17 (ENV 2) crop seasons, in GuarapuavaParana-Brazil. The soil is characterized as Dystroferric Bruno Latosol, latitude $25^{\circ} 21$ ', longitude $51^{\circ} 31^{\prime}$ and altitude $1050 \mathrm{~m}$. The climate is $\mathrm{Cfb}$ with an average temperature between 17 and $18^{\circ} \mathrm{C}$ and precipitation between 1800 and $2000 \mathrm{~mm}$ annually (NITSCHE et al., 2019).

Each of the five topcrosses resulting from the cross between the $S_{3}$ inbred lines and the respective testers were evaluated in the field, in a randomized complete block design, with three replications, in a contiguous area. Each plot consisted of two lines, 5 $\mathrm{m}$ long, spaced $0.45 \mathrm{~m}$ apart. Grain yield (GY) was evaluated from the harvest of all ears of the plot with humidity correction to $13 \%$.

The errors were submitted to the ShapiroWilk normality and homoscedasticity tests by the Bartlett test. Once these assumptions were verified, an individual analysis of variance was then performed. The residual variances of the two years were submitted to the Hartley test at 5\% and, once homoscedasticity was reported, the joint variance analysis was performed according to the design.

Having noticed that the inbred lines $\mathrm{x}$ tester interaction (ILXT) was significant by the F test, we proceeded with the AMMI-Biplot analysis (ZOBEL et al., 1988), with each tester being characterized similarly to the environment of the traditional analysis. The analysis considers the effects of inbred lines and testers as additives and the interaction of inbred lines $\mathrm{x}$ testers as multiplicative, through the analysis of the components (IPCA), with the following model:

$$
Y_{i j}=\mu+p_{i}+t_{j}+\sum_{k-1}^{n} \sqrt{ } \lambda_{k} y_{i k} \alpha_{j k}+r_{i j}+\varepsilon_{i j}
$$

Where:

$Y_{i j}$ is the average grain yield of inbred line $i$, in cross with tester $\mathrm{j}$;

$\mu$ is the general average grain yield;

$\mathrm{p}_{\mathrm{i}}$ is the effect of inbred line $\mathrm{i}$;

$t_{j}$ is the effect of tester $j$;

$\lambda_{\mathrm{k}}^{\mathrm{j}}$ is the k-th eigenvalue of the IPCA axis;

$\mathrm{y}_{\mathrm{ik}}$ is the eigenvector of the $\mathrm{i}$-th inbred line, on the $\mathrm{k}$ axis of the IPCA;

$\alpha_{\mathrm{jk}}$ is the eigenvector of the $\mathrm{j}$-th tester, on the IPCA k-axis;

$r_{i j}$ is the deviation from the interaction not explained by the principal components, retained (noise portion); 
$\mathrm{n}$ is the number of main axes retained to describe the pattern of the ILxT interaction;

$\varepsilon i_{j}$ is the average experimental error associated with the observation $(\mathrm{P}<0.05)$.

For the definition of the number of axes tested, the criterion of GAUCH \& ZOBEL (1988) was adopted, that is, the sum of the squares of the interaction, in this case SS (ILxT), up to the nth axis. The analysis of each component was also presented by the $\mathrm{F}$ test, with the degrees of freedom adjusted by the method of GOLLOB (1968) and adapted by GAUCH (2013). AMMI-Biplot analyzes were performed with the aid of the $\mathrm{R}$ and Genes programs (CRUZ, 2013; R CORE TEAM, 2020).

The result of greatest interest in the AMMI analysis is the sum of squares of the ILxT interaction, which corresponds to the sum of the eigenvalues $\left(\Sigma \lambda_{k} 2 n_{k}=1\right)$. This sum may be inflated due to the presence of noise in the response variable. In view of the above, it is necessary to adjust the interaction by the decomposition into singular values, applied to the ILxT interaction matrix, that is, it can be decomposed into several principal components according to the lowest value of the degree of freedom for inbred lines or testers (I-1 or J-1) (Table 1).

In the AMMI analysis, the ILxT interaction is the object of the singular value decomposition (SVD). When obtaining the matrix of interactions, we know that the sum of squares of the eigenvalues of this matrix, obtained through the SVD, provides the exact sum of squares of the interaction. However, this analysis seeks to discard noise, leaving in the model only the components necessary to explain this interaction (GAUCH \& ZOBEL, 1988). For the determination of the principal useful components, the methodology described by GOLLOB (1968) was followed. According to the Gollob F test for the grain yield variable in both assessment environments, 2 of the 4 interaction axes were significant, which leads to the selection of the AMMI2 model, which makes it possible to plot the averages vs. IPCA1 (AMMI1) and IPCA1 vs IPCA2 (AMMI2). The AMMI1 biplot contains the variation of the main additive effects of testers and inbred lines, displayed horizontally in the graph (abscissa axis), and the variation of the multiplicative effects of the interaction, viewed vertically (ordinate axis). The AMMI2 biplot displays only the multiplicative effects of the interaction contained in the first two principal components and dispersed in both ordinates of the graph. The interpretation of the biplot graph, in addition to providing information on the stability of inbred lines and testers, also allows the identification of specific superior crosses by observing the magnitude and signal of the scores represented in the interaction axis (GAUCH, 2013).

\section{RESULTS AND DISCUSSION}

There was a significant interaction between inbred lines and testers in both assessment environments (Table 1), an effect commonly observed

Table 1 - Analysis of main additive effects and multiplicative interaction of grain yield of 30 crossed maize inbred lines with 5 testers evaluated in 2 environments.

\begin{tabular}{|c|c|c|c|c|c|c|c|c|c|c|c|c|c|}
\hline \multicolumn{2}{|l|}{ SV } & DF & SS & MS & $\mathrm{F}$ & $\mathrm{P}>\mathrm{F}$ & \multicolumn{2}{|c|}{ SV } & DF & SS & MS & $\mathrm{F}$ & $\mathrm{P}>\mathrm{F}$ \\
\hline \multicolumn{2}{|c|}{ Inbred lines } & 29 & 117.323 & 4.046 & 2.238 & 0.00 & \multicolumn{2}{|c|}{ Inbred lines } & 29 & 145.317 & 5.011 & 3.357 & 0.00 \\
\hline \multicolumn{2}{|l|}{ Testers } & 4 & 83.480 & 20.870 & 11.543 & 0.00 & \multicolumn{2}{|c|}{ Testers } & 4 & 32.392 & 8.098 & 5.424 & 0.00 \\
\hline \multicolumn{2}{|c|}{ Interaction } & 116 & 209.732 & 1.808 & 1.768 & 0.00 & \multicolumn{2}{|c|}{ Interaction } & 116 & 173.172 & 1.493 & 1.768 & 0.00 \\
\hline IPCA1 & $41.37 \%$ & 32 & 86.783 & 2.712 & 2.652 & 0.00 & IPCA1 & $43.49 \%$ & 32 & 75.319 & 2.354 & 2.788 & 0.00 \\
\hline IPCA2 & $72.53 \%$ & 30 & 65.363 & 2.179 & 2.131 & 0.00 & IPCA2 & $70.90 \%$ & 30 & 47.474 & 1.582 & 1.874 & 0.00 \\
\hline IPCA3 & $89.44 \%$ & 28 & 35.454 & 1.266 & 1.238 & 0.20 & IPCA3 & $86.89 \%$ & 28 & 27.683 & 0.989 & 1.171 & 0.26 \\
\hline IPCA4 & $100 \%$ & 26 & 22.133 & 0.851 & 0.833 & 0.70 & IPCA4 & $100 \%$ & 26 & 22.696 & 0.873 & 1.034 & 0.42 \\
\hline \multicolumn{2}{|c|}{ Mean error } & 210 & 214.725 & 1.023 & & & \multicolumn{2}{|c|}{ Mean error } & 210 & 177.295 & 0.844 & & \\
\hline
\end{tabular}

The mean error originates from the individual analyses of variance (weighted mean of the MSerror's of the crossings with the 5 testers, reduced to the level of averages). 
in several studies (MARCONDES et al., 2016; ROSA et al., 2020; SESAY et al., 2016). This indicated that the inbred lines present a different performance in crosses with the different testers, justifying the study of the performance of both genitors in order to identify the magnitude of the interaction between them.

Although significant, the interaction may not always indicate a difference in the performance of the genotypes because, in some cases, the interaction is detected due to the non-adjustment of the data to the statistical model used. It is then necessary to associate the additive model to the multiplicative model in order to elucidate the real effects of the interaction, thus justifying the use of the AMMI model (AHMED et al., 2017; DUARTE \& VENKOVSKY, 1999; GAUCH \& ZOBEL, 1988; RAMALHO et al., 2012).

According to the analysis of variance and the decomposition of the sum of squares of the interaction, it was reported that the first two principal components (IPCA 1 and IPCA 2) were significant by the Gollob F test in both assessment environments. In environment 1 , IPCA 1 explained $41.37 \%$ of the variation in SS (ILxT) with 32 degrees of freedom. IPCA 2 explained $31.16 \%$ of the variation in SS (ILxT) with 30 degrees of freedom. In environment 2, IPCA 1 explained $43.49 \%$ of the variation in SS (ILxT) with 32 degrees of freedom. IPCA 2 explained $27.41 \%$ of the variation in SS (ILxT) with 30 degrees of freedom (Table 1).

As the two principal components explained $72.53 \%$ of the total variation of the interaction in environment 1 and $70.90 \%$ in environment 2, they were sufficient to assess stability and adaptability of the inbred lines and testers, as well as the effect of the interaction using the AMMI biplot, as described by DUARTE \& VENCOVSKY (1999). Superior results to $70 \%$ of the variation explained by the first two principal components were also observed by KUMAR et al. (2020) (92.61\%), RUSWANDI et al., 2020 (81.70\%) and HONGYU et al. (2015), who used the AMMI model and explained $81.7 \%$ of the interaction for data related to grain yield in maize.

According to GAUCH (1988), the first singular axis of the AMMI analysis must capture the highest percentage of the "pattern" of the interaction. With the subsequent accumulation of the dimensions of the axes, there is a decrease in the percentage of this "pattern"; and consequently, an increase in "noise". This suggested that most of the interaction (ILxT) is explained by the first two singular axes, a fact that occurs in both trials.

When the ILxT interaction is verified in topcross evaluations, in most cases through the analysis of variance and the use of the additive model, this one is only mentioned without considering the analysis of the partition or the respective contribution of each genitor for a significant effect of the interaction (CANDIDO et al., 2020; HEINZ et al., 2019). Given the above, the AMMI analysis can enable a more efficient interpretation by allowing the partition of the effect of the interaction and; consequently, its study and analysis in more detail (CHARCOSSET et al., 1993).

In the Biplot AMMI1 (Figures 1 and 4), the $\mathrm{X}$ axis represents grain yield and the $\mathrm{Y}$ axis represents the inbred lines $\mathrm{X}$ testers interaction (IPCA 1) (GAUCH, 2013). The inbred lines and testers that are closer to zero are characterized as the most stable or, in this case, had similar performance in the crossings with the different testers. Those furthest from zero are more adapted or have the best combination with specific testers and contributed more to the inbred lines $\mathrm{x}$ testers interaction (IPCA 1) (SALVO et al., 2021).

The MLP102 and 70.H26.1 testers showed the lowest averages for grain yield considering the additive effects represented on the horizontal axis (Figure 1). The MLP102 and 60.H23.1 testers were the ones that most contributed to the interaction, presenting high amplitude in the scores for the multiplicative effects observed in the IPCA 1 axis (CHARCOSSET et al., 1993; GAUCH, 2013; GAUCH \& ZOBEL 1988). Inbred lines 96.3, 41.3, 218.3, and 138.5 had the highest averages for grain yield, and considering the multiplicative effects, they expressed the lowest coordinates on the IPCA 1 axis, reflecting low contribution to the interaction and good stability (Figure 1). Tester 70.H26.1 demonstrated good stability, and despite low average values for grain yield, this one at specific crossings showed high values exceeding the average of the others (Figure 2). The P30B39 tester expressed grain yield above the observed average and intermediate value for stability (HONGYU et al., 2015; YAN et al., 2007).

Considering the crosses with all testers in environment 1, the average grain yield was 10490 $\mathrm{kg} \mathrm{ha}^{-1}$ (Figure 2). The 60.H23.1 tester was the one with the highest number of crosses above the average, showing a high adaptability of the inbred lines to this tester (HONGYU et al., 2015).

Considering the biplot of principal components IPCA 1 and IPCA 2 in which the multiplicative effects are represented (Figure 3), tester 70.H26.1, together with inbred lines 96.3, 16.5, 205.1 and 121.1, were the ones that presented the highest stability and the lowest contribution to the interaction (CHARCOSSET et al., 1993). 


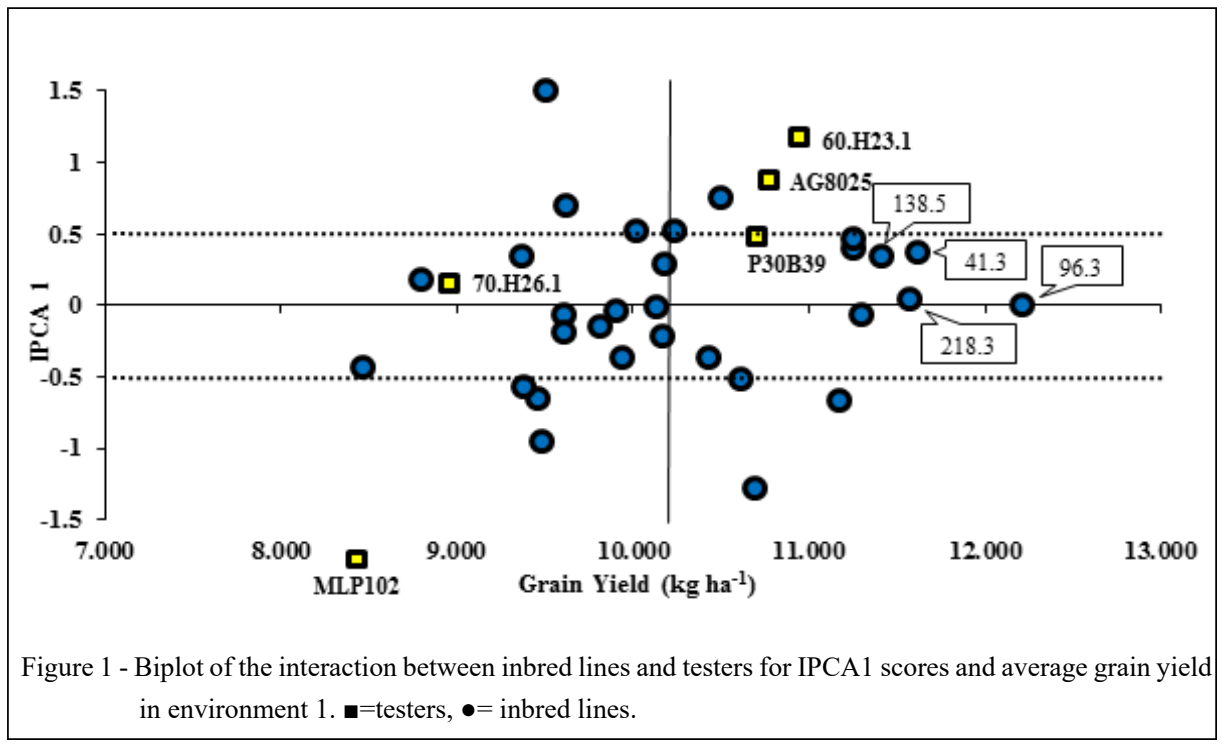

The MLP102, AG8025 and 60.H23.1 testers held most of the interaction, suggesting that they are not the most suitable for topcross, as they influence the relative merit of the evaluated inbred lines. Regarding tester 70.H26.1, in addition to high stability, a wide adaptability to most of the inbred lines evaluated can be verified considering both the additive and multiplicative effects of the interaction (CANDIDO et al., 2020; HEINZ et al., 2019).

The position of the scores in the biplot, in addition to values related to interaction, can provide important information when considering the angle

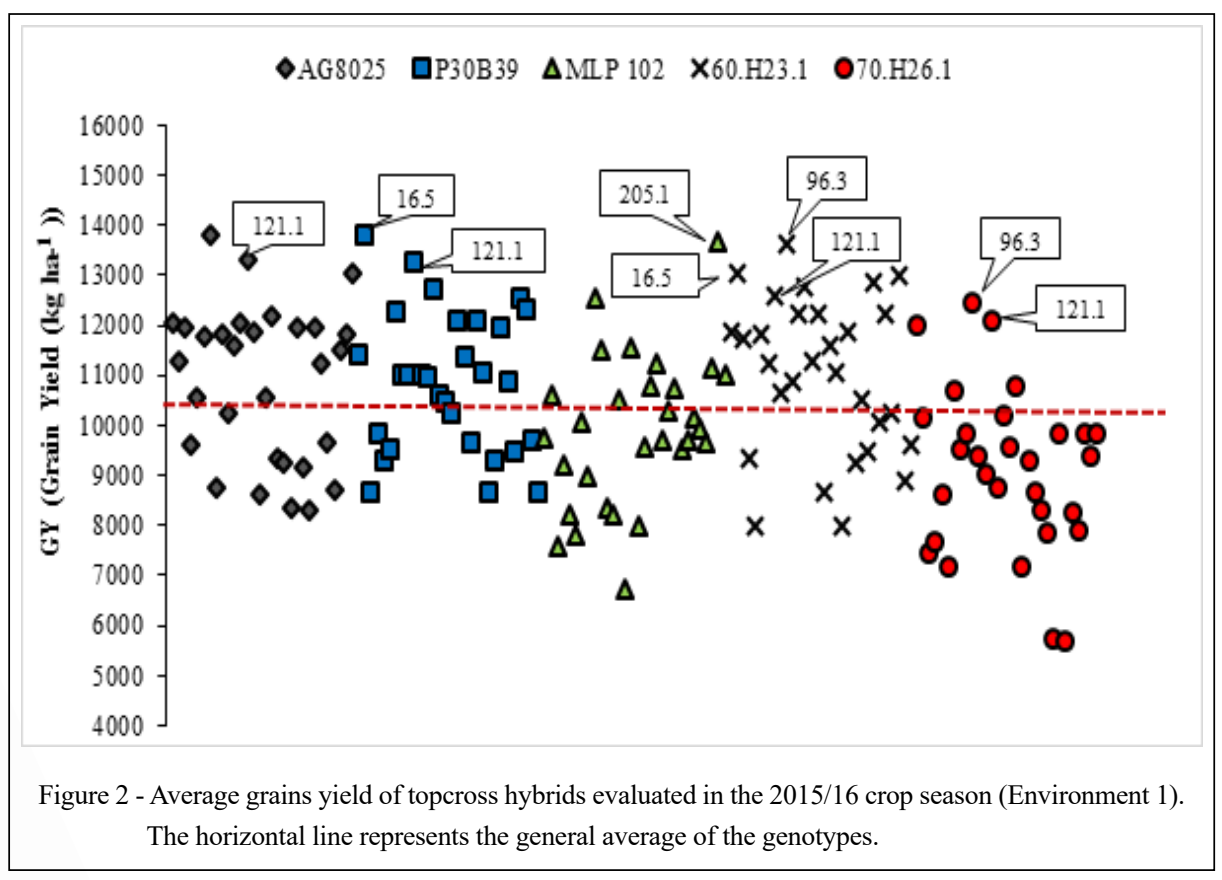

Ciência Rural, v.52, n.9, 2022. 


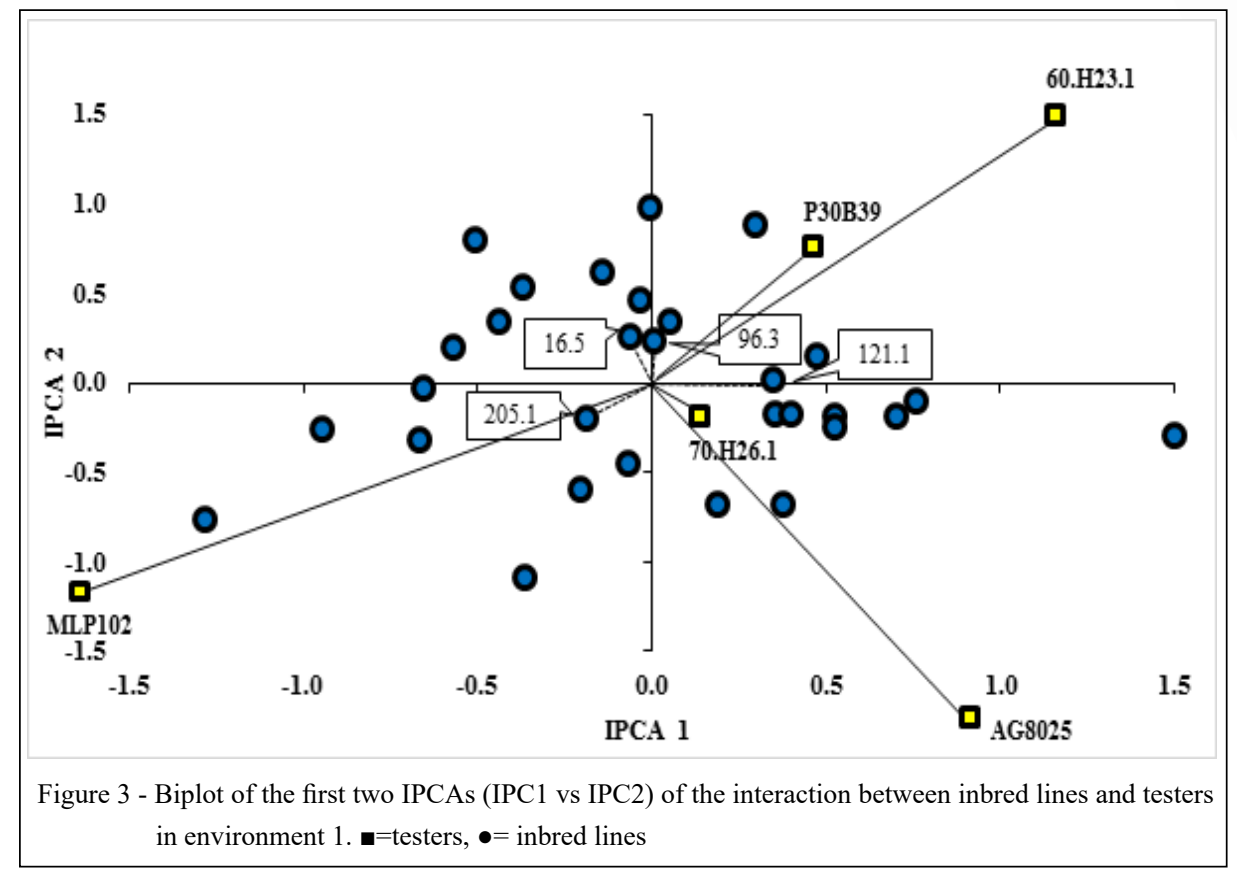

established between each observed point (GAUCH, 2013). A straight line can be drawn from the origin of the biplot to the position of a tester or inbred line being called a "tester vector" or "inbred line vector", so that, from these vectors, the specific interactions between a tester and an inbred line can be viewed. The interpretation rule is based on the performance of an inbred line or tester, in which: it is better than the general average if the angle between its vector and the tester's vector is $<90^{\circ}$, it is worse than the average if the angle is $>90^{\circ}$ (because the cosine of an obtuse angle is less than 0 ) and it is close to the average if the angle is approximately equal to $90^{\circ}$ (YAN et al., 2007).

According to what has been described, it is possible to verify in the figure 2 , based on the vectors, that the highlighted inbred lines 96.3 and 16.5 presented higher averages in crosses with testers $\mathrm{P} 30 \mathrm{~B} 39$ and $60 . \mathrm{H} 23.1$ (BALESTRE et al., 2009; GAUCH, 2013). The 121.1 inbred line showed high averages with the AG8025, P30B39, 60.H23.1 and 70.H26.1 testers. Only in relation to the MLP102 tester did it present values lower than the general average. Inbred line 205.1 presented high values in a crossing with the MLP102 tester, a value close to the average in a crossing with the AG8025 tester and lower values with the other testers in which the presence of obtuse angles was evidenced (Figure 3). This information can be confirmed in figure 2 .
The angle between the scores also allows interpretations regarding the correlation between testers in which angles lower than $90^{\circ}$ indicate positively correlatable testers and higher angles indicated testers with a negative correlation (YAN et al., 2007). The angles between the P30B39 and 60.H23.1 testers allow to infer a high positive correlation, as observed between testers 70.H26.1 and AG8025 (Figure 3). For the MLP102 tester, the angle indicated a negative correlation with all the other testers. Testers P30B39 and 60.H23.1 have a low correlation with testers 70.H26.1 and AG8025 due to the angle between them being close to $90^{\circ}$. The correlation between testers can be an important analysis, especially when referring to the selection for future crossings in which highly correlated testers can be discarded, allowing a reduction in the number of testers used. According to the biplot of the scores in environment 1, even though there was a correlation between some testers, there was no formation of groups (CROSSA et al., 1991; DI SALVO et al., 2021).

According to figure 4 , in environment 2, testers MLP102 and AG8025, together with tester 60.H23.1, this time the most discrepant, were the ones that most contributed to the interaction considering the multiplicative effect observed in the IPCA1 axis. Inbred lines 96.3 and 218.3 again stood out with 


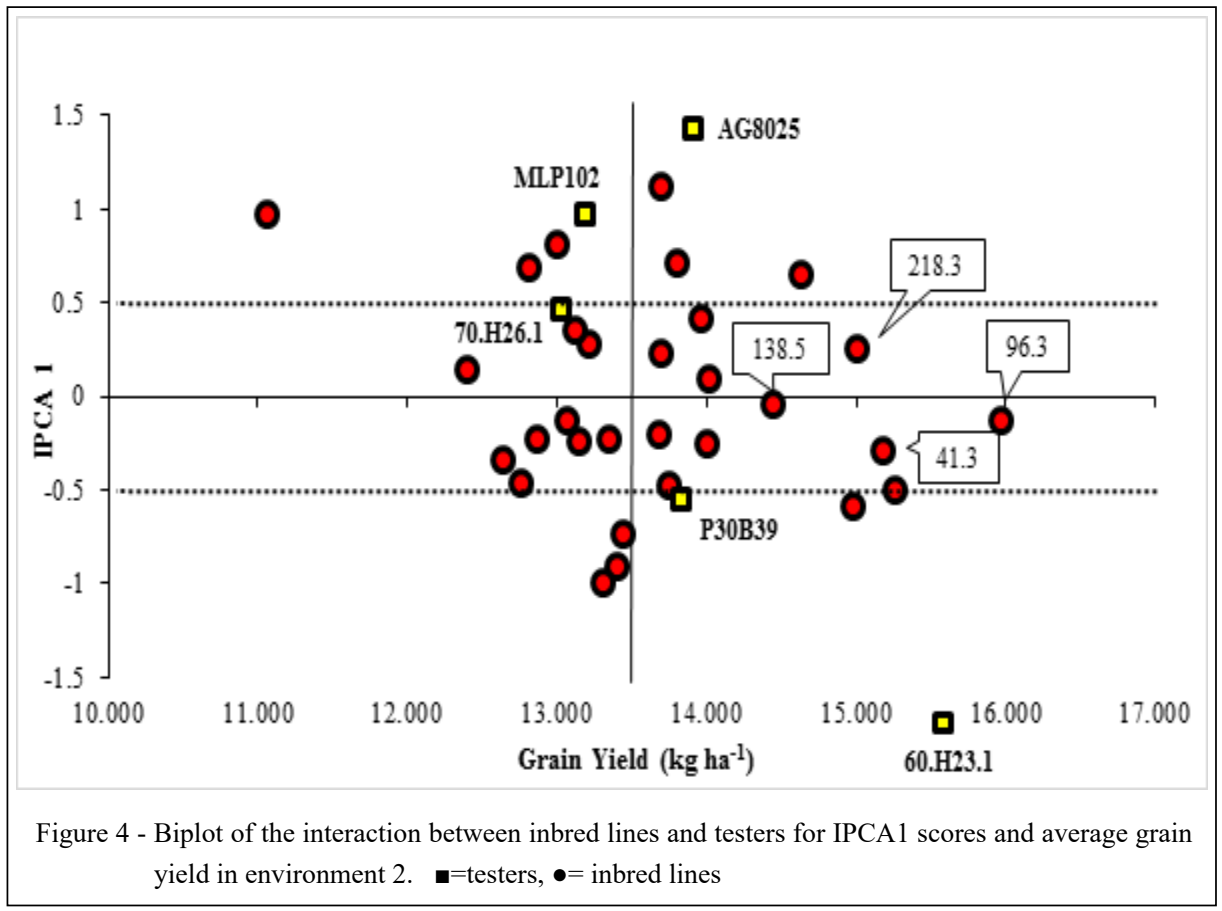

high grain yield at crossings and stability, as did inbred lines 41.3 and 138.5, which expressed lower coordinates on the IPCA 1 axis; and consequently, contributed a little to the interaction (Figure 4). As in environment 1, tester 70.H26.1 demonstrated good stability considering the multiplicative effects, despite low average values for grain yield. In relation to the P30B39 tester, it presented grain yield higher than the average observed and intermediate values for stability.

Regarding crosses with all testers in environment 2, the average grain yield was $13764 \mathrm{~kg} \mathrm{ha}^{-1}$ (Figure 5). Again, tester 60.H23.1 was the one with the highest number of crosses above the average, reaffirming the general adaptability of inbred lines to this tester (HONGYU et al., 2015, MUSHAYI et al., 2020).

According to the biplot of the principal components IPCA 1 and IPCA 2 (AMMI2) in environment 2 (Figure 6), inbred lines 96.3, 199.2, 172.1 and 121.1 showed greater stability at crossings and low contribution to the interaction. Conversely, in this environment, all testers showed low stability, contributing significantly to the interaction. This fact may be related to the gene expression that can be changed according to the environmental influence and directly reflect on the ILxT interaction (HONGYU et al., 2015). Another fact that must be considered is the influence of "noises" in the analysis, since the quality of the biplot adjustment was $70.90 \%$, instead of $100 \%$ (YAN, 2011; ZOBEL et al., 1988).

In environment 2, it can be seen that the highlighted inbred lines 96.3, 121.1 and 199.2 presented angles lower than $90^{\circ}$ (Figure 6). This result can be seen in figure 5 . For the other testers, according to the observed angle, it is possible to verify inferior performance with the exception of inbred line 96.3 in a cross with tester 70.H26.1, which remained in the average. The 172.1 inbred line showed high values for grain yield with the 70.H26.1 tester and remained on average in a cross with the 60.H23.1 tester. In relation to the other testers, it presented values lower than the general average (Figure 6).

Regarding the correlable testers, a positive correlation can be seen between testers 60.H23.1 and P30B39 and between testers AG8025 and MLP102. Among the pairs mentioned, the correlation was negative. The 70.H26.1 tester showed a negative correlation with the $60 . \mathrm{H} 23.1$ tester and a positive correlation with AG8025. In relation to the other testers, the angle was close to $90^{\circ}$, suggesting a low correlation. The AG8025 and MLP102 testers can be grouped due to the proximity of their positioning. 


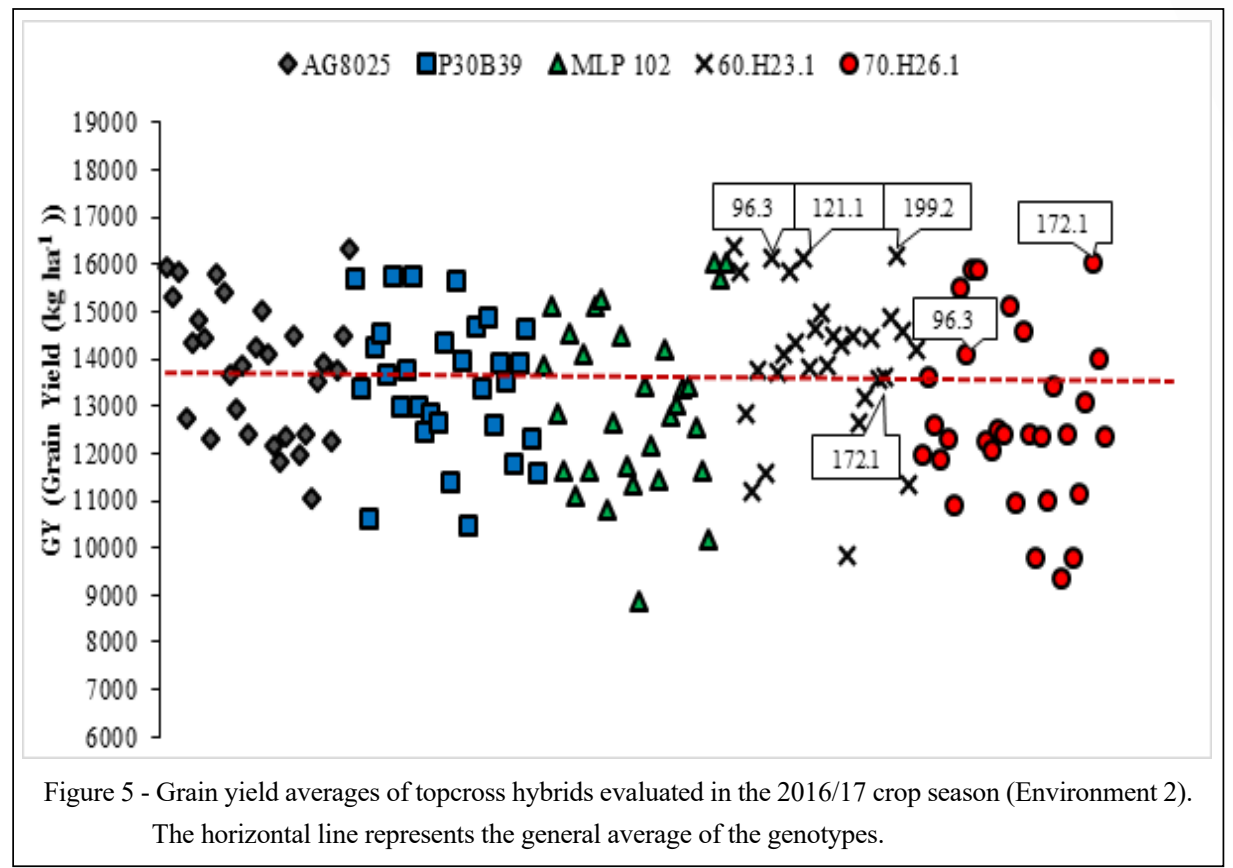

In both environments, in general, the testers were the ones that most contributed to the interaction, thus reaffirming the difficulty of choosing a suitable tester for a high number of inbred lines (VENCOVSKY \& BARRIGA, 1992). However, despite what has been described, it was reported that the AMMI analysis can be used as an important alternative to explore the additive and multiplicative effects of the ILxT interaction and in the selection of testers and inbred lines, studies that can often generate erroneous

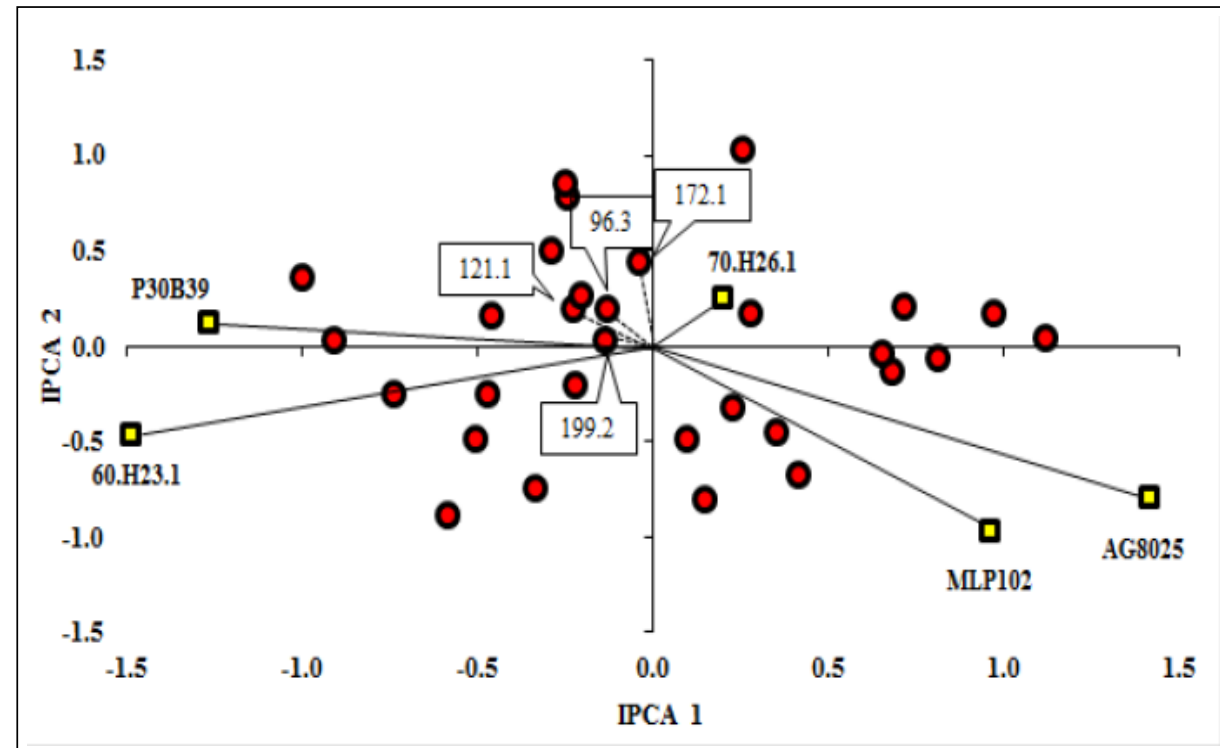

Figure 6 - Biplot of the first two IPCAs (IPC1 vs IPC2) of the interaction between inbred lines and testers in environment 2 . $\mathbf{m}=$ testers, $\bullet=$ inbred lines

Ciência Rural, v.52, n.9, 2022. 
conclusions in analyzes based only on estimates of genetic parameters and additive effects (CANDIDO et al., 2020; ROSA et al., 2020).

\section{CONCLUSION}

Inbred line 96.3 presented the most stable performance and the highest grain yield considering the crossing with the set of testers in both environments. The tester $60 . \mathrm{H} 23.1$ showed general adaptability of inbred lines in both environments.

The 70.H26.1 tester is considered the most stable and the most recommended for topcrosses. The best specific combinations were $96.3 \times 60 . \mathrm{H} 23.1$.

\section{ACKNOWLEDGEMENTS}

To Conselho Nacional de Desenvolvimento Científico e Tecnológico (CNPq), for financial support; to Universidade Estadual do Centro-Oeste (UNICENTRO), for providing the facilities used in the research; and to Coordenação de Aperfeiçoamento de Pessoal de Nível Superior (CAPES), for financial support (Finance Code 001).

\section{DECLARATION OF CONFLICT OF INTEREST}

The authors declare no conflict of interest. The founding sponsors had no role in the design of the study; in the collection, analyses, or interpretation of data; in the writing of the manuscript, and in the decision to publish the results.

\section{AUTHORS' CONTRIBUTIONS}

All authors contributed equally for the conception and writing of the manuscript. All authors critically revised the manuscript and approved of the final version.

\section{REFERENCES}

AHMED, S. et al. Combining ability estimates in maize (Zea mays L.) Through line $\times$ tester analysis. Bangladesh Journal of Agricultural Research, v. 42, p. 425-436, 2017. Available from: $<$ https://doi.org/10.3329/bjar.v42i3.34501>. Accessed: Jul. 10, 2020. doi: 10.3329/bjar.v42i3.34501.

BALESTRE, M. et al. (2009). Genotypic stability and adaptability in tropical maize based on AMMI and GGE biplot analysis. Genetics and molecular research. v. 8, p. 1311-1322, 2009. Available from: <https://doi.org/10.4238/vol8-4gmr658>. Accessed: Jul. 1, 2021. doi: 10.4238/vol8-4gmr658.

BOŢOVIĆ, D. et al. Assessment stability of maize lines yield by GGE-biplotanalysis. Genetika, v. 50, p. 755-770, 2018. Available from: <https://doi.org/10.2298/GENSR1803755B >. Accessed: Jul. 1, 2020. doi: 10.2298/GENSR1803755B.

CANDIDO, W. S. et al. Selection of top cross hybrids for green maize yield via REML/Blup method. Australian Journal of Crop
Science, v. 14, p. 172-178, 2020. Available from: <https://doi. org/10.21475/ajcs.20.14.01.p2061>. Accessed: Jan. 23, 2021. doi: 10.21475/ajcs.20.14.01.p2061.

CHARCOSSET, A. et al. Modelling interaction from top-cross design data and prediction of F1 hybrid value. Agronomie Sciences, v. 13, p. 597-608, 1993. Available from: <https:// doi.org/10.1051/agro:19930704>. Accessed: Jul. 10, 2020. doi: 10.1051/agro:19930704.

CROSSA, J. et al. AMMI adjustment for statistical analysis of an international wheat yield trial. Theoritical and Applied Genetics, 81: 27-37, 1991. Available from: <https://doi.org/10.1007/ bf00226108>. Accessed: Sep. 08, 2020. doi: doi.org/10.1007/ bf00226108.

CRUZ, C. D. GENES - a software package for analysis in experimental statistics and quantitative genetics. Acta Scientiarum, v. 35 , p. 271-276, 2013. Available from: <https:// doi.org/10.4025/actasciagron.v35i3.21251>. Accessed: Jul. 18, 2020. doi: 10.4025/actasciagron.v35i3.21251.

DAVIS, R. L. Report of the plant breeder. Agricultural Experimental Station, San Jose. p. 14-15, 1927.

DI SALVO et al. Regional multi-environment analysis of corn productivity and yield stability as impacted by hybrid maturity. Field Crops Research, v. 262, p. 1-9, 2021. Available from: $<$ https://doi.org/10.1016/j.fcr.2020.108025>. Accessed: Jul. 12, 2021. doi: 10.1016/j.fcr.2020.108025.

DUARTE, J. B. and VENCOVSKY, R. Interação genótipos x ambientes: uma introdução à análise "AMMI". Ribeirão Preto: FUNPEC. 1999. Available from: <https://www.researchgate. net/publication/235941257 Interacao genotipos $\mathrm{x}$ ambientes Uma_introducao_a_analise_AMMI>.Accessed: Jul. 10, 2020.

GOLLOB, H. F. A statistical model which combines features of factor analitic and analysis of 271 variance techniques. Psychometrika, v. 33, p. 73-115, 1968. Available from: <https:// doi.org/10.1007/bf02289676>. Accessed: Jan. 17, 2021. doi: $10.1007 / \mathrm{bf02289676.}$

GAUCH, H. G. A simple protocol for AMMI analysis of yield trials. Crop Science, v. 53, n. 1860-1869, 2013. Available from: $<$ https://doi.org/10.2135/cropsci2013.04.0241>. Accessed: Feb. 18, 2020. doi:10.2135/cropsci2013.04.0241.

GAUCH, H. G. and ZOBEL RW. Predictive and postdictive success of statistical analysis of yield trials. Theorical and Applied Genetics, v. 76 n. 1-10, 1988. Available from: <https:// doi.org/10.1007/BF00288824>. Accessed: Mar. 11, 2020. doi: $10.1007 / \mathrm{BF} 00288824$.

HEINZ, R. et al. Selection of maize top-crosses for different nitrogen levels through specific combining ability. Bragantia, v. 78, n. 208-214, 2019. Available from: <https://doi.org/10.1590/16784499.20180196>. Accessed: Jan. 19, 2021. doi: 10.1590/16784499.20180196 .

HONGYU, K. et al. Comparação entre os modelos AMMI e GGE Biplot para os dados de ensaios multi-ambientais. Revista Brasileira de Biometria, v. 33, n. 139-155, 2015. Available from: $<$ https://www. researchgate.net/publication/289952730>. Accessed: Apr. 03, 2020.

KUMAR, P. et al. GGE biplot based stability analysis of

Ciência Rural, v.52, n.9, 2022. 
experimental hybrids for baby corn purpose and green fodder. Range Management and Agroforestry, v. 41, n. 60-66. 2020. Available from: <https://www.researchgate.net/publication/343230997_GGE_ biplot_based_stability_analysis_of_experimental_hybrids_for_baby_ corn_purpose_and_green_fodder>. Accessed: Jan. 21, $20 \overline{2} 1$.

MARCONDES, M. M. et al. Breeding potential of $\mathrm{S}_{4}$ maize lines in topcrosses for agronomic and forage traits. Acta Scientiarum, v. 38, n. 307-315, 2016. Available from: <https://doi.org/10.4025/ actasciagron.v38i3.28307>. Accessed: Feb. 23, 2020. doi: 10.4025/ actasciagron.v38i3.28307.

MUSHAYI, M. et al. Multi-environmental evaluation of maize hybrids developed from tropical and temperate lines. Euphytica v. 216 , n. 84 (2020). Available from: < https://doi.org/10.1007/ s10681-020-02618-6>. Accessed: Jul. 12, 2021. doi: 10.1007/ s10681-020-02618-6.

NITSCHE, P. R. et al. Atlas climático do Estado do Paraná. Londrina: Instituto Agronômico do Paraná. 2019. Available from: $\quad<$ http://www.idrparana.pr.gov.br/system/files/publico/ agrometeorologia/atlas-climatico/atlas-climatico-do-parana-2019. pdf>. Accessed: Jan. 10, 2021.

R CORE TEAM. R: A language and environment for statistical computing. R Foundation for Statistical Computing, Vienna, Austria. 2020. Available from: <https://www.R-project.org $>$. Accessed: Dec. 18, 2019.

ROSA et al. Forage potential of S3 corn progenies in topcrosses and selection of testers of different genetic bases, Pesquisa Agropecuária Brasileira, p. 1-11, 2020. Available from: <https:// doi.org/10.1590/s1678-3921.pab2020.v55.01283>. Accessed: Jan. 13, 2021. doi: 10.1590/s1678-3921.pab2020.v55.01283.

RUSWANDI, D. et al. Stability and Adaptability of Yield among Earliness Sweet Corn Hybrids in West Java, Indonesia. International Journal of Agronomy, p. 1-9, 2020. Available from: <https://doi:10.1155/2020/4341906>. Accessed: Jan. 10, 2021. doi: $10.1155 / 2020 / 4341906$.

SALVO, J. I. D. et al. Regional multi-environment analysis of corn productivity and yield stability as impacted by hybrid maturity. Field Crop Research, v. 262, 2021. Available from: <https://doi. org/10.1016/j.fcr.2020.108025>. Accessed: Mar. 15, 2021. doi: 10.1016/j.fcr.2020.108025.

SESAY, S. et al. Genetic variability, heritability and genetic advance studies in top-cross and three way cross maize (Zea mays L) hybrids. Maydica, v. 61, p. 1-7, 2016. Available from: $<$ https://www.researchgate.net/publication/311845141 Genetic variability_heritability_and_genetic_advance_studies_in_topcross and three-way cross maize Zea Mays L hybrids $>$. Accessed: Jan. 17, 2021.

VENCOVSKY, R. and BARRIGA, P. Genética biométrica no fitomelhoramento. Ribeirão Preto: Sociedade de Genética. 1992.

YAN, W. et al. GGE Biplot vs. AMMI analysis of genotype-byenvironment data. Crop Science, v. 47, p. 643-656, 2007. Available from: $<$ https://doi.org/10.2135/cropsci2006.06.0374>. Accessed: Dec. 28, 2020. doi: 10.2135/cropsci2006.06.0374.

YAN, W. GGE biplot vs. AMMI graphs for genotype-byenvironment data analysis. Journal of the Indian Society of Agricultural Statistics, v. 65, p.181-193, 2011. Disponível em: $<$ http://isas.org.in/jisas/jsp/volume/vol65/issue2/06-Weikai\%20 Yan.pdf>. Accessed: Jan. 09, 2021.

ZOBEL, RW et al. Statistical analysis of a yield trial. Agronomy Journal, v. 80, p. 388-393, 1988. Available from: $<$ https://doi.org/10.2134/agronj1988.00021962008000030002 $\mathrm{x}>$. Accessed: Dec. 29, 2020. doi: 10.2134/agronj1988.0002 $1962008000030002 x$. 